\title{
Preservice teachers perceptions about the use of blended learning in a science education methods course
}

\author{
Özkan Yılmaz ${ }^{1 *}$ (D) and Kathy L. Malone ${ }^{2}$
}

\author{
* Correspondence: ozkanchip@ \\ gmail.com; ozkanyilmaz@erzincan. \\ edu.tr \\ ${ }^{1}$ Faculty of Education, Department \\ of Mathematics and Science \\ Education, Erzincan Binali Yildirim \\ University, Erzincan, Turkey \\ Full list of author information is \\ available at the end of the article
}

\begin{abstract}
The purpose of this quantitative study was to determine the effectiveness of blended learning within the context of a science education methods course for early childhood elementary preservice teachers in Turkey. Elementary teachers historically fear science and avoid using it in their classes. This course was blended to allow the students to experience active science learning during face to face sessions. Student perceptions about their experiences in a blended methods course were collected using a previously validated survey. The data analysis of the post-test only survey research design demonstrated that students' perceptions were positive towards the use of blended learning within their science education methods course. However, the analysis determined that students felt that certain technical aspects of the blended learning environment hindered their learning.

Keywords: Science instruction, Blended learning, Higher education, Learning environment, Elementary preservice teachers, Science methods courses
\end{abstract}

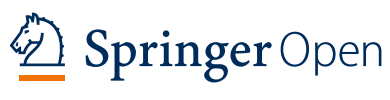

\section{Introduction}

The creation of innovative learning environments in higher education has continued to gain importance in multiple disciplines (Tabata \& Johnsrud, 2008). The incorporation of computers and other digital technologies into university classes has been shown to correlate with higher academic achievement on the part of students (Zucker, 2008). Using technology in education has shown positive effects on (1) student achievement, (2) class engagement, and (3) supporting students' special needs (Zucker, 2008). Learning environments, incorporated with information technology have been shown to have specific benefits for learning science in terms of (1) promoting cognitive development, (2) allowing for a wider range of student experiences, (3) supporting students' selfmanagement ability, and (4) supporting students' development of conceptual understanding by facilitating data collection and collaboration (Webb, 2008).

Creating innovative learning environments has helped to ensure that learning and teaching can be carried out in accordance with defined goals. One of the emerging

(c) The Author(s). 2020 Open Access This article is licensed under a Creative Commons Attribution 4.0 International License, which permits use, sharing, adaptation, distribution and reproduction in any medium or format, as long as you give appropriate credit to the original author(s) and the source, provide a link to the Creative Commons licence, and indicate if changes were made. The images or other third party material in this article are included in the article's Creative Commons licence, unless indicated otherwise in a credit line to the material. If material is not included in the article's Creative Commons licence and your intended use is not permitted by statutory regulation or exceeds the permitted use, you will need to obtain permission directly from the copyright holder. To view a copy of this licence, visit http://creativecommons.org/licenses/by/4.0/. 
learning environments that have shown to be welcomed by students is blended learning (Lim \& Morris, 2009).

\section{Current state of blended learning}

There are numerous definitions used for blended learning (BL) environments in research (Graham, 2017). This paper is closely aligned with the idea that BL is a learning environment consisting of the planned usage of both face-to-face and online teaching environments in a pedagogically sound manner to allow for more active science learning during face to face class sessions (Picciano, 2009; Stein \& Graham, 2014). Thus, in the context of this study BL was considered a pedagogy that makes use of the best attributes of each learning environment to promote the learning of science.

Many schools today face similar problems and challenges. All stakeholders should work together to provide training opportunities for learners to prepare them for the future (OECD, 2006). Access to students and teachers in learning material and technology is an important issue worldwide. In this respect, they need culturally appropriate learning materials and technologies. For this new approach, which is thought to have an important potential for improving student learning by people who do research and practice in the field of blended learning, it is thought that it would be more appropriate to collaborate and develop universally. For this purpose, it is important to carry out detailed studies for each region to obtain specific information about the regional problems and specific solutions for each region, as well as to make transitions between different contexts. BL applications in different parts of the world develop various perspectives on common BL problems that can be applied and adapted to various contexts. Thus, more efficient improvements and better educational opportunities will be provided for students all over the world (Spring, Graham, \& Hadlock, 2016). Although there is a wide variation of $\mathrm{BL}$ applications worldwide, there are also strategic similarities. Graham (2006), stated that BL can be evaluated in three categories: (1) enabling blends (i.e., focus on addressing issues of access and convenience), (2) enhancing blends, and (3) transforming blends (i.e., blends that allow for a radical transformation of the pedagogy).

\section{Benefits and challenges of blended learning}

Garrison and Vaughan (2008) considered BL to be essential for student learning as no single method or learning environment would be sufficient for all students in any particular subject. The use of BL has been shown to have multiple benefits in several contexts. For example, BL has been studied in economics (Zhang, Zhang, \& Seiler, 2014), vocational schools (Tsai, Shen, \& Tsai, 2011), and science (Oikawa et al., 2013). Benefits of BL over that of traditional courses have included the ability to allow students to study at their own pace (Caulfield, 2011; Linder \& E., 2017), improved student outcomes (Means, Toyama, Murphy, Bakia, \& Jones, 2010; Tsai et al., 2011), increased student engagement (Baepler, Walker, \& Driessen, 2014; Smith, Groves, Bowd, \& Barber, 2012) and increased student satisfaction (Martínez-Caro \& Campuzano-Bolarín, 2011). Many benefits of BL might be caused by the flipped nature of the environment. In many traditional classrooms, students are passive for longer periods but this passiveness is not observed as often in blended learning environments (Baepler et al., 2014). 
They noted that since students enrolled in BL classrooms were able to listen to a significant portion of the course content online, more time was gained for the creation of a face-to-face (F2F) learning environment in which active participation increased.

However, the findings of improved student outcomes have been challenged by other studies such as Oikawa et al. (2013). Oikawa et al. (2013) determined that while students had positive attitudes towards BL in chemistry their academic achievement was not significantly affected. Thus, it seems that the specific designs that were used and the needs of the students may have to be carefully considered to enhance student learning as much as possible. Yllmaz (2017) determined that undergraduate students enrolled in BL courses because they thought the BL course design would provide for (1) better information sharing, (2) more practical and functional interactions, (3) easier course preparation and evaluation, (4) increased student engagement in research, (5) increased study time, (6) better preparation for the lecture, (7) greater cooperative learning, and (8) innovative instruction. Thus, since students have specific reasons for enrolling in BL courses it is very important to study their perceptions of these courses after taking them. However, Graham (2017) found that $42.1 \%$ of all blended learning research studies focused on the cognitive and behavioural domains while only $25.4 \%$ of studies focused on areas such as student perceptions, experiences, and anticipations. Thus, there is a gap in the field in terms of student perceptions of BL courses.

\section{Blended learning in the context of teacher education}

When BL is used within the scope of teacher education courses, students enjoyed taking part in the learning environment (Akkoyunlu \& Soylu, 2006). However, a metaanalysis conducted by Means, Toyama, Murphy, and Baki (2013) found that very few of the blended learning studies focused on teacher education. Teacher education research articles have focused on the use of BL within the context of teacher education focused on educational technology (Demirer \& Sahin, 2013), language learning (Motteram, 2006) preservice English teachers (Kurt, 2017), general preservice teaching skills (Alayyar, Fisser, \& Voogt, 2012; Heba \& Nouby, 2008; Jahjouh, 2014; Yeh, Y.-C., 2010), in-service teachers (King, 2002; Owston, Sinclair, \& Wideman, 2008), educational leadership (Adams \& Ross, 2014; Namyssova et al., 2019; Ross et al., 2011), and general science courses specifically designed for preservice primary teachers using flipped classroom approaches (Jeong, Cañada-Cañada, \& González-Gómez, 2018; Tomas, Doyle, \& Skamp, 2019). However, only two studies were located that focused on the use of BL in preservice science methods courses and those focused on its effects on secondary science teachers, specifically on their level of academic achievement (Heba \& Nouby, 2008; Jahjouh, 2014) and the level of peer to peer cooperation (Heba \& Nouby, 2008). Thus, there is a gap in the research since the use of BL has not been assessed in terms of science methods courses for elementary preservice teachers (EPT).

The lack of studies focused on elementary preservice science methods courses using BL is troubling since this type of learning environment could assist in their training and ultimately increase science learning in elementary classrooms. For example, elementary preservice teachers have been shown to have a fear of science (Bursal \& Paznokas, 2006; Tosun, 2000). Appleton and Kindt (1999) found that when elementary teachers fear science they were less likely to use appropriate teaching methods such as 
inquiry-oriented pedagogy. This finding suggested that EPT might have low needs selfefficacy towards science teaching. This is troubling since it has been shown that primary teachers' self-efficacy beliefs in science affect their students' self-efficacy towards science, especially their female students (Oppermann, Brunner, \& Anders, 2019). This is a concern since females make up the majority of students in college but only a third of those majoring in STEM fields (OECD, 2019). One recent study determined that having EPT participate in classes focused on inquiry-oriented activities can shift their attitudes towards science which could ultimately assist in raising young students' selfefficacy in science (Riegle-Crumb et al., 2015). One possible method that could allow for more active science learning in science methods courses for elementary preservice teachers could be the use of blended learning. Within a blended learning science methods course, EPT could work on their content knowledge and pedagogical knowledge during the online learning portion of the course. This use of the online learning environment would allow for more class time for the EPT to practice teaching and learning via inquiry-oriented science pedagogies. Currently, in a traditional F2F science methods course time includes the teaching of science content and pedagogical content knowledge leaving less time for practicing with hands-on inquiry methods.

As shown above, only a few BL studies have focused on the effect of blended learning on elementary preservice teachers and those have been only within the context of general science courses designed for this group of students. While these studies found increases in science content knowledge and increased engagement they also determined that elementary preservice teachers seemed to prefer not to engage independently with difficult science concepts (Jeong et al. (2018). This is troubling as it may have demonstrated a lack of self-efficacy on the part of EPT towards science as well as a fear of science. Neither of these studies attempted to identify student perceptions in terms of what portions of the general science course supported or hampered their learning. Thus, studies are needed that determine EPT perceptions not only about the BL learning course in general but also about the F2F and online learning environment (OLE) portions of the BL to determine how each supports their science learning. Also, their perceptions of how the blending of the two environments of the BL course support their learning are needed if science teacher educators are to support not only science learning but also self-efficacy towards science teaching within the context of science methods courses for EPT. Thus, there is a gap in the research in terms of EPT perceptions and challenges within the context of blended elementary science methods courses.

\section{Research purpose}

In order for BL to be used effectively, students' opinions about the different aspects of the BL course must be taken into account in order to design a more effective BL course. Thus, it is important to evaluate learning environments through the eyes of students. For this reason, the opinions of the students about the new more hands-on F2F environment created within the BL class as well as their opinions about the separate OLE are needed to assess the effectiveness of the course as a whole. Also, this information is needed to make shifts in the two separate environments as well as suggesting how to blend them as a whole. In addition, the problems encountered by students because of the technological aspects of the BL course must be assessed to facilitate course 
changes that can limit student frustration. Thus, this quantitative case study aimed to determine the experiences and opinions of preservice elementary teachers enrolled in a blended learning science methods course at one university in Turkey towards these four main areas of the blended learning environment.

The following research questions were targeted:

1. What are the experiences and opinions of Elementary Preservice Teachers (EPT) about their learning within the face-to-face (F2F) portion of a blended learning science methods course (SMC)?

2. What are the experiences and opinions of EPT towards their learning within the online portion of a blended learning SMC?

3. What are the experiences and opinions of students about the blending of face-toface and online learning environments in a blended learning SMC?

4. What are the technical problems associated with the implementation of a blended learning SMC?

\section{Methodology}

\section{Research design}

The purpose of this study was to determine the perceptions of EPT concerning how different portions of a BL environment affected their learning. Because this study focused on the rich and vivid description of events in a BL science methods course for EPT, the logical research design was a case study (Hitchcock, Hitchcock, \& Hughes, 1995). To determine anonymous views about the different learning environments used within the BL SMC, (i.e., F2F, OLE) a quantitative survey design was chosen to identify trends in attitudes, opinions, behaviours, and characteristics in the small case that could be applied to a larger group of EPT in other contexts (Creswell, 2012).

\section{Blended learning in the context of a science methods course}

In the science methods course, BL was composed of two main sections; online events that were completed by students and F2F activities which were continuations of the online activities that allowed students to apply learning from the OLE. The online events focused on individual performance, while the F2F activities focused on cooperative group activities during active learning sessions. Figure 1 further describes the blended learning environment.

\section{Implementation of blended learning}

Blended learning was carried out during one semester of the Science Education Methods Course. The course included techniques of teaching basic science concepts and scientific thinking skills, preparation and application of activities and materials according to these techniques, as well as teaching science concepts covered in preschool education programs. In this course, MOODLE was used for online activities conducted outside the classroom.

Weekly events were organized as online activities that were completed before each F2F class session. Classroom discussion and sharing activities during the F2F portion of the course were a continuation of the individual events students conducted in the 


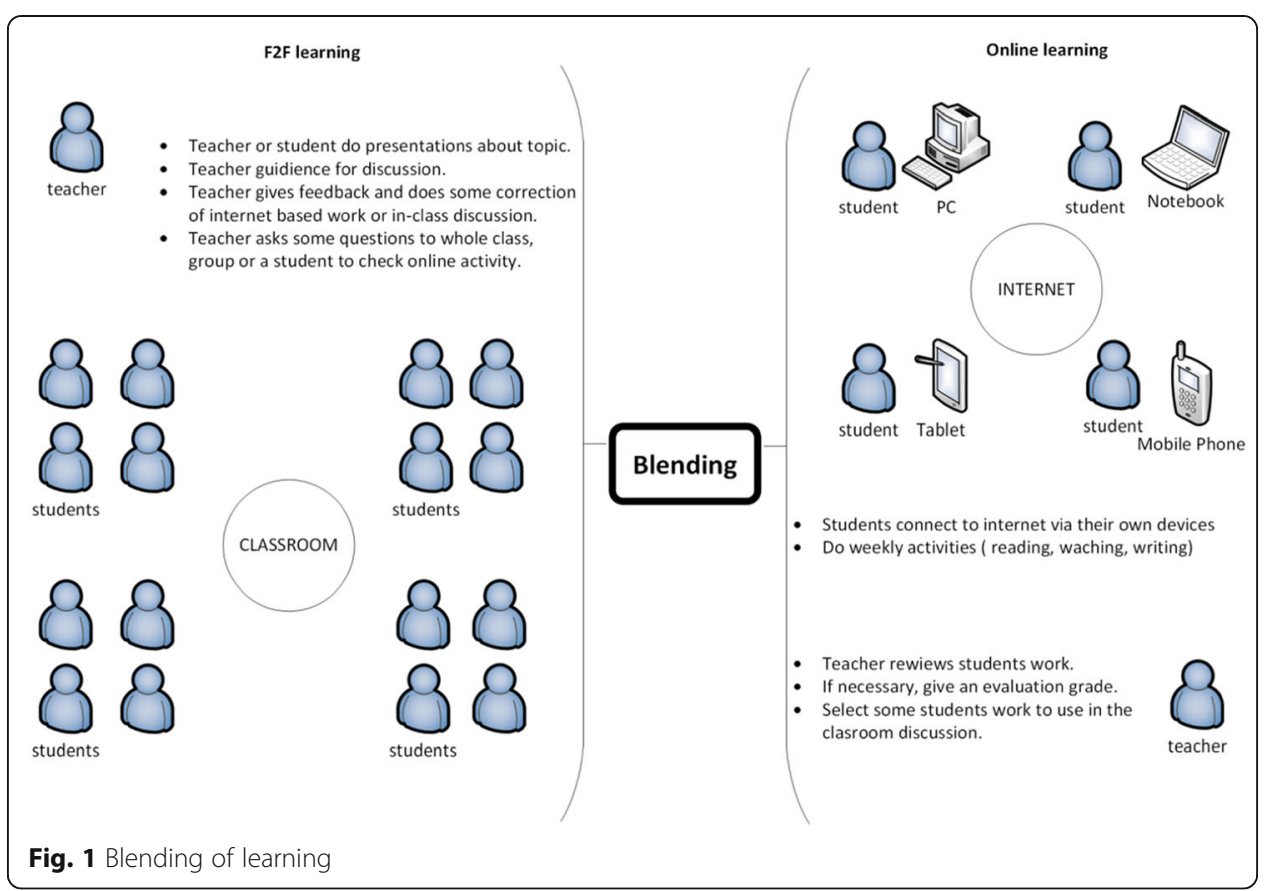

online environment. The blending of these two learning environments, where one environment is a continuation of the other, was designed as shown in Table 1.

\section{Out-of-the-classroom activities}

The online individual activities were planned in coordination with the active learning activities scheduled during the F2F sessions. After the individual OLE activities were completed, the lessons were submitted to the teacher for evaluation and feedback comments. This assessment was completed before each F2F session. Students were able to look at their assessment at the end of each activity week on their MOODLE page before attending the F2F sessions.

\section{In-classroom activities}

Changes were made in the activities conducted in the original face-to-face traditional class when the blended course was designed. These changes included new ways to integrate the online activities (which were traditionally taught in a lecture format) with the new in-class F2F active learning class activities. The various teaching methods and techniques used during the F2F sessions included student presentations, sharing, discussion, inquiry lessons, and question-answer. These methods were used to provide a multifaceted interaction during the classroom environment.

Table 1 BLENDING of online and face-to-face environments

\begin{tabular}{ll}
\hline Learning Environment: INTERNET/MOODLE & Learning Environment: SCHOOL/CLASSROOM \\
\hline Online, Distance Training & F2F formal training \\
Individual Activities & In-class social activities \\
Flexible time for learning & Predetermined fixed time for learning \\
Individual-specific and student-controlled planning & Teacher-guided student group activities \\
\hline
\end{tabular}




\section{Example of a blended activity}

Concept teaching was an important topic in the SMC. On the MOODLE page, the instructor uploaded several references concerning the unit topic. The references included concept networks, concept maps, and concept cartoons. Students also used these and other internet resources to research the science topic assigned for the week. Following their online activities and research, students constructed their concept maps about the science topic (e.g. nature and events, erosion). Students explained in a short paragraph what their intent was for the different segments of the concept map (i.e., linkages between concepts). They uploaded the concept map to the MOODLE class site before the F2F portion of the course. Their instructor reviewed all of the concept maps and evaluated them before the F2F meeting. The results of the teacher assessment were used to further enhance and modify the activities planned for the F2F meeting.

During the F2F segment of the course, the teacher selected some of the students' work and asked them to explain their thoughts to the whole class. After student presentations, the teacher started a discussion about the selected concept maps by asking leading questions of the presenters and the rest of the students. Thus, all the students voiced their opinions about the similarities and differences between the various concept maps. This allowed the teacher to help the students reach consensus while including his feedback to the students. This also allowed for facilitating student learning by filling in the gaps that students had in their conceptual understanding using inquiry-oriented techniques. These types of activities were designed to demonstrate not only science concepts but the methods the EPT could use to teach these concepts in their future classrooms thus enhancing their pedagogical content knowledge.

\section{Participants}

The participants of the blended learning research study consisted of students enrolled in the department of early childhood education and the SMC was taught by the faculty of education at a Turkish University. Students were selected by using purposeful sampling. The criteria used to select student participants included the following: (1) enrolment in the BL Science Education Methods Course; (2) ability to use basic computer and internet tools (determined by completion of computer assessments); and 3) regular course attendance. Participants consisted of a total of 42 people: 2 males and 40 females. The research sample's male/female ratio was similar to that of the overall class enrolment. The average age of participants was calculated as 21,2 years.

\section{Instrument}

The experiences and opinions of the students towards blended learning were assessed by using a previously validated and reliable 5-point Likert-style survey instrument developed by Cabı and Gülbahar (2013). The survey contained 55-items with choices ranging from strongly agree (5) to strongly disagree (1). The midpoint choice was labelled as neutral (3). This instrument was initially assessed using 314 undergraduate students attending a university located in Turkey. These scores were analyzed for internal reliability and the Cronbach alpha score for the 
survey was 0.94. In this study, the survey was administered online as a postassessment at the end of the term on a voluntary and anonymous basis.

This scale included four factors (a) Face-to-face learning environment (F2F), (b) Online learning environment (OLE), (c) Blended learning environment (BLE,), and (d) Technical dimensions (TD). The items contained in each factor will be discussed in further detail in the data and discussion sections that follow.

\section{Data analysis}

In psychological tests, an equal spacing level is used to convert survey data into a standard (Cooligan, 1999). Both parametric and nonparametric tests have been used in the analysis of survey data (Bazeley, 2004). Parametric tests are preferred since they are accepted as having greater validity. To use parametric tests, the data must be equally spaced or equally proportional (Lodico, Spaulding, \& Voegtle, 2006). Creswell (2012), stated that there is no guarantee that the intervals or item choices specified in Likert type tests are equal. However, it has been determined that there is no significant difference between the use of parametric tests and the use of non-parametric tests during the evaluation of study results (Murray, 2013). Another important determinant of whether the parametric tests could be used is the need to have a normal distribution of data (Field, 2009). Gravetter and Wallnau (2007) suggested that to have a normal distribution of the data, the number of suitable samples must be 30 or greater. If the number of samples is low $(n<30)$, nonparametric tests would be more suitable (Hoskin, 2011).

In this study, the decision was made to analyse the data using parametric test techniques. The $q-q$ plot normality test was used to determine if the data obtained from the study were distributed normally. The first two choices, strongly disagree and disagree (i.e., 1 and 2), were evaluated negatively and the two choices, agree and strongly agree (i.e., 4 and 5), were evaluated positively. The significance of the results was determined using a one-sample $t$-test and measures of central tendency of the data (arithmetic mean, standard deviation).

In this study, since student opinions about the specifics of the four main factors (i.e., F2F, OLE, BL, and TD) were of utmost importance to answering each of the research questions it was necessary to analyze the student results for each survey item contained in each factor to obtain detailed perceptions from the students. Thus, elementary preservice teachers' opinions about the use of BL in the context of an SMC were able to be examined in greater detail.

\section{Limitations of the study}

The obtained findings, conclusions, and recommendations are limited to the use of blended learning in science education method courses in one higher education setting. The study group was selected using the purposeful sampling method. Thus the generalizability of the results obtained in this study is limited (Gould, 2002). Also, the results from a survey study may not reveal in-depth issues faced by the EPT as an interview study might have accomplished. However, the usage of the survey did allow for a greater number of student perceptions to be assessed. 


\section{Results}

To demonstrate significant differences in the experiences and opinions of the students about the blended learning course a one-sample $t$-test was used. Since the Likert type scale used in this study consisted of five-item choices, the forecast point was set as the midpoint of the range of data or three (i.e., neutral) (Kent State University Libraries, 2017). To be able to perform the single sample $t$-test, the data must be independent of each other and the data set must show a normal distribution.

The normality tests for all data and factors (i.e., F2F, OLE) were performed via a $Q-Q$ plot test using SPSS software. As can be seen in Table 2, the data shows a normal distribution in terms of factors as well as for total score since the data points plotted are aligned mostly along a straight line (Field, 2009).

Thus, a one-sample $t$-test can be performed for this data set given that it displays a normal distribution.

According to the results of the one-sample $t$-test (Table 3), the null hypothesis that there was no significant difference between the expected mean and the realized mean is rejected with a confidence interval of $95 \%$. When the difference between these averages was examined, it was observed that there is a difference of more than one item choice for both F2F and BLE as shown by the mean differences in Table 3 (1,08 and 1,12, respectively). In addition, there was a difference of over a half of an item choice between the mean of both the OLE and TD factors and the forecasting point of an average of 3 .

As each experience and opinion about blended learning has a unique importance, the sub-items of each factor were also analysed using one-sample $t$ tests.

\section{Elementary preservice teachers opinions and experiences about the face to face portion of the blended learning science methods course}

The one-sample $t$-test sub-item results for the F2F portion of the BL SMC are shown in Table 4. When all the items were examined, it was seen that all of the values were above the determined forecasting point (i.e., 3) and were significantly different. These results suggest that the BL course does have a significant effect on the F2F learning environment according to the students. Specifically, the results suggest that when BL is used in a science teacher education methods course, preservice teachers have a positive attitude towards the F2F or in-class learning environment.

Table 2 Normality tests of sub-factors and total (Q-Q plot tests)

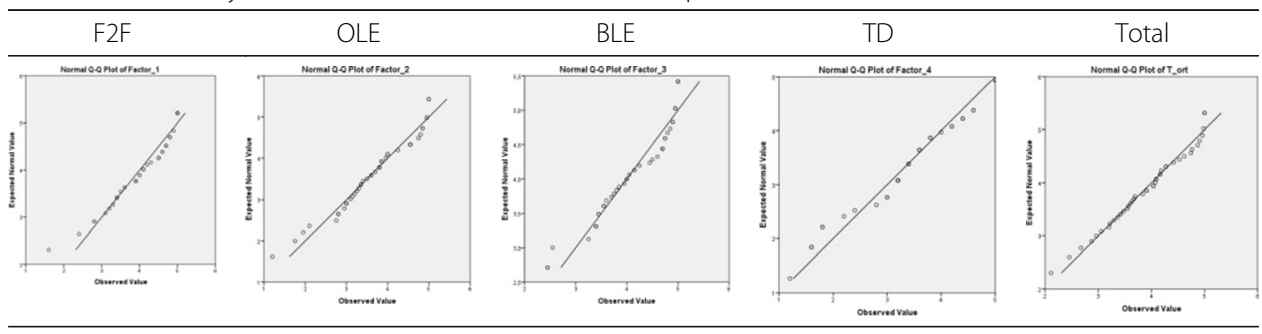


Table 3 One sample t-test

\begin{tabular}{|c|c|c|c|c|c|c|c|c|}
\hline \multicolumn{5}{|c|}{ One-Sample Statistics } & \multicolumn{4}{|c|}{ One-Sample Test } \\
\hline Items & $N$ & Mean & Standard. Deviation & Standard Error Mean & $\bar{t}$ & $d f$ & Sig. (2-tailed) & Mean Difference \\
\hline $\mathrm{F} 2 \mathrm{~F}$ & 42 & 4,08 & 816 & 125 & 8,63 & 41 &, 000 & 1,08 \\
\hline OLE & 42 & 3,64 &, 930 &, 143 & 4,46 & 41 &, 000 &, 640 \\
\hline BLE & 42 & 4,12 & ,731 & ,112 & 9,97 & 41 &, 000 & 1,12 \\
\hline TD & 42 & 3,61 & 1,08 & , 166 & 3,68 & 41 &, 001 & ,614 \\
\hline Total Score & 42 & 3,89 & ,731 &, 112 & 7,94 & 41 &, 000 & 896 \\
\hline
\end{tabular}

Elementary preservice teachers opinions and experiences about the online learning environment of the blended learning science methods course

The one-sample $t$-test results for the online learning environment (OLE) associated with the BL SMC are shown in Table 5. When the OLE items were examined, it was determined that while several factor items have higher values than the determined forecasting point, they were not significantly different from the forecasting value. These items were as follows:

- "I liked studying very much" (OLE6),

- "I felt more sense of responsibility than in a face-to-face learning environment" (OLE8),

- "Using online communication tools made me feel I was not alone" (OLE9), and

- "The course content was prepared in accordance with individual differences." (OLE20).

Thus, the OLE factor, which was composed of 20 items in total, showed no significant difference in only 4 out of 20 factor items. The remaining 16 items appeared to be positive with a significant difference, see Table 5 . These results suggested that BL does have a positive overall effect on the OLE learning environment. Specifically, the results suggested that when an OLE is used in a science teacher education methods course, preservice teachers have an overall positive attitude towards the online learning environment.

Table 4 One sample t-test for Face-to-face Learning Environment. Items in bold are significant

\begin{tabular}{|c|c|c|c|c|c|c|c|c|}
\hline \multicolumn{5}{|c|}{ One-Sample Statistics } & \multicolumn{4}{|c|}{ One-Sample Test } \\
\hline Items & $\mathrm{N}$ & Mean & Standard Deviation & Standard Error Mean & $t$ & $d f$ & $\begin{array}{l}\text { Significance. } \\
\text { (2-tailed) }\end{array}$ & Mean Difference \\
\hline F2F1 & 42 & 3,92 &, 947 &, 146 & 6,35 & 41 &, 000 &, 928 \\
\hline F2F2 & 42 & 3,97 &, 949 &, 146 & 6,66 & 41 &, 000 &, 976 \\
\hline F2F3 & 42 & 3,92 & 1,06 &, 164 & 5,63 & 41 &, 000 & ,928 \\
\hline F2F4 & 42 & 4,14 & 1,11 &, 172 & 6,63 & 41 &, 000 & 1,14 \\
\hline F2F5 & 42 & 4,52 &, 633 &, 097 & 15,57 & 41 &, 000 & 1,52 \\
\hline F2F6 & 42 & 4,14 & 1,00 &, 154 & 7,39 & 41 &, 000 & 1,14 \\
\hline F2F7 & 42 & 4,14 & 1,15 &, 178 & 6,38 & 41 &, 000 & 1,14 \\
\hline F2F8 & 42 & 4,11 & 1,06 &, 164 & 6,81 & 41 &, 000 & 1,11 \\
\hline F2F9 & 42 & 4,14 & ,977 &, 150 & 7,58 & 41 &, 000 & 1,14 \\
\hline F2F10 & 42 & 3,83 & 1,12 &, 173 & 4,80 & 41 & ,000 & ,833 \\
\hline
\end{tabular}


Table 5 One sample $t$-test results for online learning environment

\begin{tabular}{|c|c|c|c|c|c|c|c|c|}
\hline \multicolumn{5}{|c|}{ One-Sample Statistics } & \multicolumn{4}{|c|}{$\underline{\text { One-Sample Test }}$} \\
\hline Items & N & Mean & $\begin{array}{l}\text { Standard } \\
\text { Deviation }\end{array}$ & $\begin{array}{l}\text { Standard Error } \\
\text { Mean }\end{array}$ & $\mathrm{t}$ & df & $\begin{array}{l}\text { Significance(2- } \\
\text { tailed) }\end{array}$ & $\begin{array}{l}\text { Mean } \\
\text { Difference }\end{array}$ \\
\hline OLE1 & 42 & 3,76 & 1,26 & , 195 & $\begin{array}{l}3, \\
90\end{array}$ & 41 &, 000 &, 761 \\
\hline OLE2 & 42 & 3,42 & 1,14 &, 176 & $\begin{array}{l}3 \\
64\end{array}$ & 41 &, 001 &, 642 \\
\hline OLE3 & 42 & 3,59 & 1,14 & , 177 & $\begin{array}{l}3 \\
35\end{array}$ & 41 &, 002 &, 595 \\
\hline OLE4 & 42 & 3,85 & 1,07 &, 165 & $\begin{array}{l}5 \\
18\end{array}$ & 41 &, 000 &, 857 \\
\hline OLE5 & 42 & 3,52 & 1,27 & , 196 & $\begin{array}{l}2, \\
66\end{array}$ & 41 &, 011 &, 523 \\
\hline OLE6 & 42 & 3,33 & 1,18 &, 182 & $\begin{array}{l}1, \\
82\end{array}$ & 41 &, 075 & ,333 \\
\hline OLE7 & 42 & 3,45 & 1,31 & 202 & $\begin{array}{l}2, \\
23\end{array}$ & 41 &, 031 &, 452 \\
\hline OLE8 & 42 & 3,40 & 1,38 &, 212 & $\begin{array}{l}1 \\
90\end{array}$ & 41 &, 064 &, 404 \\
\hline OLE9 & 42 & 3,19 & 1,36 &, 210 & 90 & 41 &, 371 & , 190 \\
\hline OLE10 & 42 & 3,64 & 1,22 &, 189 & $\begin{array}{l}3, \\
39\end{array}$ & 41 &, 002 &, 642 \\
\hline OLE11 & 42 & 3,88 & 1,19 &, 184 & $\begin{array}{l}4, \\
78\end{array}$ & 41 &, 000 &, 880 \\
\hline OLE12 & 42 & 3,90 & 1,03 & , 159 & $\begin{array}{l}5 \\
68\end{array}$ & 41 & ,000 &, 904 \\
\hline OLE13 & 42 & 4,07 & 1,13 & , 175 & $\begin{array}{l}6 \\
12\end{array}$ & 41 & ,000 & 1,07 \\
\hline OLE14 & 42 & 4,11 & ,992 & ,153 & $\begin{array}{l}7 \\
30\end{array}$ & 41 & ,000 & 1,11 \\
\hline OLE15 & 42 & 3,61 & 1,16 & , 180 & $\begin{array}{l}3 \\
43\end{array}$ & 41 & ,001 & ,619 \\
\hline OLE16 & 42 & 3,90 & 1,00 & , 155 & $\begin{array}{l}5 \\
82\end{array}$ & 41 & ,000 & 904 \\
\hline OLE17 & 42 & 3,64 & 1,18 & , 182 & $\begin{array}{l}3, \\
51\end{array}$ & 41 & ,001 & ,642 \\
\hline OLE18 & 42 & 3,64 & 1,10 & , 169 & $\begin{array}{l}3 \\
78\end{array}$ & 41 & ,000 & ,642 \\
\hline OLE19 & 42 & 3,38 & 1,16 & , 180 & $\begin{array}{l}2 \\
11\end{array}$ & 41 & ,041 & ,380 \\
\hline OLE20 & 42 & 3,23 & 1,26 & , 195 & $\begin{array}{l}1 \\
22\end{array}$ & 41 & ,230 & ,238 \\
\hline
\end{tabular}

Elementary preservice teachers opinions and experiences about the blending of the F2F and $B L$ portions of the blended learning science methods course

The one-sample $t$-test results for the blended learning factor are shown in Table 6 . When all the items were examined, it was seen that all the values were significantly above the determined forecasting point. These results suggested that the blending of the F2F and OLE environments was an effective learning environment for preservice elementary teachers enrolled in a BL science education methods course. Specifically, the results suggested that when $\mathrm{BL}$ is used in science teacher education, preservice teachers develop a positive attitude towards the use of the BL learning environment. 
Table 6 One sample t-test for blended learning environment

\begin{tabular}{|c|c|c|c|c|c|c|c|c|}
\hline \multicolumn{5}{|c|}{ One-Sample Statistics } & \multicolumn{4}{|c|}{$\underline{\text { One-Sample Test }}$} \\
\hline Items & $\mathrm{N}$ & Mean & $\begin{array}{l}\text { Standard } \\
\text { Deviation }\end{array}$ & $\begin{array}{l}\text { Standard. Error } \\
\text { Mean }\end{array}$ & $t$ & $d f$ & $\begin{array}{l}\text { Significance(2- } \\
\text { tailed) }\end{array}$ & $\begin{array}{l}\text { Mean } \\
\text { Difference }\end{array}$ \\
\hline BL1 & 42 & 4,45 &, 739 &, 114 & $\begin{array}{l}12 \\
73\end{array}$ & 41 &, 000 & 1,45 \\
\hline BL2 & 42 & 4,16 &, 881 &, 135 & 8,58 & 41 &, 000 & 1,16 \\
\hline BL3 & 42 & 3,90 & 1,07 &, 166 & 5,44 & 41 &, 000 &, 904 \\
\hline BL4 & 42 & 3,92 & ,997 & ,153 & 6,03 & 41 &, 000 & ,928 \\
\hline BL5 & 42 & 4,45 &, 832 &, 128 & $\begin{array}{l}11 \\
30\end{array}$ & 41 &, 000 & 1,45 \\
\hline BL6 & 42 & 4,19 & 1,04 &, 160 & 7,40 & 41 &, 000 & 1,19 \\
\hline BL7 & 42 & 3,88 & 1,01 &, 156 & 5,61 & 41 &, 000 &, 880 \\
\hline BL8 & 42 & 4,47 &, 833 &, 128 & $\begin{array}{l}11 \\
47\end{array}$ & 41 &, 000 & 1,47 \\
\hline BL9 & 42 & 4,23 &, 932 &, 143 & 8,60 & 41 &, 000 & 1,23 \\
\hline BL10 & 42 & 4,28 &, 944 &, 145 & 8,82 & 41 &, 000 & 1,28 \\
\hline BL11 & 42 & 4,07 & 1,04 & , 161 & 6,64 & 41 & ,000 & 1,07 \\
\hline BL12 & 42 & 3,92 & 1,19 & 184 & 5,02 & 41 & ,000 & ,928 \\
\hline BL13 & 42 & 3,61 & 1,14 & , 176 & 3,49 & 41 & ,001 & 619 \\
\hline BL14 & 42 & 3,92 & 1,06 & 164 & 5,63 & 41 & ,000 & ,928 \\
\hline BL15 & 42 & 4,09 & ,957 & , 147 & 7,41 & 41 & ,000 & 1,09 \\
\hline BL16 & 42 & 4,40 & ,828 & , 127 & $\begin{array}{l}10 \\
99\end{array}$ & 41 &, 000 & 1,40 \\
\hline BL17 & 42 & 4,02 & 1,15 & , 178 & 5,73 & 41 & ,000 & 1,02 \\
\hline BL18 & 42 & 4,50 & ,833 & , 128 & $\begin{array}{l}11 \\
66\end{array}$ & 41 &, 000 & 1,50 \\
\hline BL19 & 42 & 4,02 & 896 & , 138 & 7,39 & 41 & ,000 & 1,02 \\
\hline BL20 & 42 & 3,95 & 986 & 152 & 6,25 & 41 & ,000 & ,952 \\
\hline
\end{tabular}

Elementary preservice teachers opinions and experiences concerning any technical difficulties of the blended learning science methods course

The one-sample $t$-test results of the fourth factor, technical dimension (TD), are shown in Table 7. When all the items were examined, it was seen that all of the values were above the determined forecasting point and were significantly different. The five items for the TD factor included:

- "I felt alone and unhappy." (TD1).

- "I have difficulty in delivering the assignments on time" (TD2).

Table 7 One sample $t$-test for Technical Dimensions

\begin{tabular}{|c|c|c|c|c|c|c|c|c|}
\hline \multicolumn{5}{|c|}{ One-Sample Statistics } & \multicolumn{4}{|c|}{ One-Sample Test } \\
\hline Items & $\mathrm{N}$ & Mean & Standard Deviation & Std. Error Mean & $t$ & $d f$ & Significance (2-tailed) & Mean Difference \\
\hline TD1 & 42 & 3,92 & 1155 & , 178 & 5,20 & 41 &, 000 & 928 \\
\hline TD2 & 42 & 3,52 & 1329 & ,205 & 2,55 & 41 &, 014 &, 523 \\
\hline TD3 & 42 & 3,52 & 1329 & ,205 & 2,55 & 41 & ,014 &, 523 \\
\hline TD4 & 42 & 3,52 & 1365 &, 210 & 2,48 & 41 & 017 &, 523 \\
\hline TD5 & 42 & 3,57 & 1416 & ,218 & 2,61 & 41 &, 012 &, 571 \\
\hline
\end{tabular}


- "I had problems with the technological infrastructure" (TD3).

- "I experienced technical difficulties" (TD4).

- "I have had problems with the internet connection." (TD5).

These results suggested that BL does cause significant technical issues for students and could affect their learning. Specifically, the results suggested that when BL is used in elementary science teacher education, these kinds of technical problems should be taken into considerations.

\section{Discussion}

In this section, the results of this study which examined the experiences and opinions of elementary preservice teachers about the blended learning environment used in their science teaching methods course are discussed in relation to the related literature. When the experiences and opinions of the students about blended learning were analyzed for each factor separately, they expressed strong views about the blended learning attributes used in the science education methods course. The directions of these differences are explained in detail below.

Elementary preservice teachers enjoy face-to-face learning environment in the context of blended learning

The face-to-face factor, consisting of ten items, revealed the experiences and opinions of the students about the in-class F2F learning environment. When each item constituting the factor was analyzed separately, it was revealed that the experience and opinions are all positive. A few examples of the survey questions covering this factor included:

- "I think I learned better. (F2F3)",

- "I communicated more easily with the teaching staff. (F2F7)",

- "I communicated more easily with my friends. (F2F4)", and

- "Teaching staff encouraged me to participate in the education process. (F2F9)".

One of the reasons why all the student opinions about the in-class learning environment were positive could be the difference in the methods used in the F2F learning environment. Traditionally in-class learning activities, according to Bergmann and Sams (2012) consist of a "flow" which includes the following:

(1) short-term, warm-up phase,

(2) control of previously assigned homework and providing feedback,

(3) presentation of the new content of the course, and.

(4) independent student-centred activities with teacher guidance.

Traditionally, these activities focus on memorizing information. However, these inclass activities should not only involve memorization by students but also include activities that promote active learning and critical thinking (Crawford, Saul, Mathews, \& Makinster, 2005). To use in-class problem-solving activities, the instructor must provide the appropriate environment for the active participation of the students as the 
learning activities must be completed within the scheduled time. The participation of the learners within the course from an emotional and behavioural point of view is directly related to the interaction between the instructor and the student (Harris, 2011). This interaction also plays an important role in the academic performance of the student (Lee, 2012). The positive view of the pupils about the in-class F2F active learning environment showed that blended learning had a significant positive effect in this case. When other academic studies related to student perceptions were examined, similar results were observed. In a study conducted by Akgündüz and Akınoğlu (2017) it was determined that 7th grade students had the opinion that "this type of course is more fun, I paid more attention to the lesson and participated in it and thus I learned better." In another study it was found that computer science students expressed opinions such as "face-to-face learning is very advantageous, we learn by discussing subjects" (Akkoyunlu \& Soylu, 2006).

In summary, the findings in this study, as well as similar academic studies in other fields, focused on blended learning have found that student experiences and opinions about the F2F learning component of the blended course are positive. It can be said that one of the main factors in the emergence of this result is that blended learning seems to have provided an in-class face-to-face learning environment that differed from the traditional classroom learning environment for teachers and students in its focus on active learning. For example, the use of active learning in undergraduate biology classes has been shown to have a positive effect on student motivation in introductory undergraduate biology classes (Armbruster, Patel, Johnson, \& Weiss, 2009; Owens, Sadler, Barlow, \& Smith-Walters, 2017). Thus, blended learning could have a positive impact on preservice elementary teachers' perceptions about science in general as well as their motivation such that it might produce increased self-efficacy. As discussed in the literature review increased self-efficacy could lead to the increased valuing of science on the part of the future students of EPT (Riegle-Crumb et al., 2015). In the case of EPT, these results may have helped to alleviate their fear of science and inquiryoriented methods thus allowing them to teach using these methods in their future classes.

While this study showed that EPT had positive experiences in the F2F portion of the BL SMC in line with past research it did not examine the nature of those experiences. It was beyond the scope of this study to determine if the BL SMC produced shifts in EPT self-efficacy towards science. In the future studies that determine student shifts in the knowledge of both science content, and science pedagogy as well as feelings about science when participating in a BL SMC should be conducted.

\section{Elementary preservice teachers experience mixed feelings about the on-line learning environment in the context of blended learning}

The analysis of the 20 survey items targeting the OLE revealed the experiences and opinions of the students about this part of the blended course. When each item constituting the factor was analyzed separately, a positive significant difference was observed in sixteen items. Four items in this factor did not show a significant difference. This result demonstrated that the students also have positive opinions and experiences about 
the online learning environment used in their science methods course. However, to better implement blended learning, it is necessary to examine the items that do not show any significant difference. The first of these items, "I liked studying independently very much." (OLE6), had an arithmetic average of 3,33. Thus, there was a partial positive tendency in the opinion of the students. However, there was not a significant difference. Because of this situation, it was necessary to find an answer to the question why students do not want to study. Human beings are curious intrinsically but the human mind is not designed to think (Willingham, 2009). Thinking refers to mental activities such as problem-solving, reasoning, reading complex structures, and conducting studies that require mental effort (Willingham, 2009). Thinking skills are divided into two groups - basic and high-level thinking skills. The basic thinking skills are grouped into three groups that include (1) remembering, (2) comprehension and (3) practicing, while the high-level thinking skills are grouped into three groups that include (1) analysis, (2) evaluation, and (3) creation (Krathwohl, 2010). Different kinds of thinking skills may be needed while studying in the online section of the blended learning course. The fact that thinking is not a simple process can be considered a reason why students said they do not like to study. Consequently, it can be said that students usually do not enjoy studying and this is not directly related to blended learning. However, one could also consider that the BL activities may have been too independent for the students especially due to their response to another item on the survey.

The survey item, "Using the online communication tools made me feel I was not alone. (OLE9)", had an arithmetic average of 3,19. This was a partial positive tendency in the opinion of the students. However, there was no significant difference. The BL online environment used in this class did not include a system that enabled students to communicate privately with each other. In addition, the activities in the OLE were designed to be completed independently.

Another non-significant survey item focusing on the OLE was, "I felt more sense of responsibility than when in a face-to-face environment (OLE8)", had an arithmetic average of 3,40. This result shows that the students felt more responsibility for completing the activities when they occurred in the face-to-face environment rather than the OLE section of the course. This might be caused due to peer pressure and the desire not to let their peers down. On the other hand, in an online environment, students were more anonymous and could more easily hide from others. So, they may have felt less sense of responsibility to not disappoint their friends.

Thus, given their responses to these three items, it is possible that EPT might require more cooperative learning engagement during the OLE. In the future, group inquiry activities in the OLE could help to alleviate EPT feeling of aloneness as well as their fear of science and help to increase their self-efficacy towards science before attending the F2F sessions (Riegle-Crumb et al., 2015). The use of peer group activities such as comparing answers or opinions online with classmates could allow them to feel more responsible to complete the OLE activities. Thus, this could help them to further their understanding, and help to increase their peer's science understanding while helping them to be more prepared for the F2F sessions.

Lastly, the survey item, "The course content was prepared in accordance with individual differences. (OLE20)", had an arithmetic average of 3,23. While this demonstrated as a partial positive tendency in the opinion of the students, it was not a significant 
difference. In blended learning, the online learning environment was designed in a coordinated manner with the activities to be carried out in the course weekly. For this reason, the online environment was used as a preliminary activity that led to the inclass educational activity. However, in this case, the online activities were not prepared considering the individual learning differences of the students, thus the fact that there is no significant difference in the opinions of the students is an unexpected outcome. However, this seems to be a lack in the BL course showing the need to have alternate activities to allow for more individualized instruction. For example, in the future activities could allow for student choice. For example, they could be allowed to either listen to a lecture or a video about the science topic being studied or read an online article. This could further assist EPT in learning science and overcoming their fear of science.

In summary, when the findings for the OLE factor were examined, it was been found that the opinions of the students were significantly positive in the case of the majority of the survey items pertaining to this factor. In addition to this, it was found that the reason for the unwilling attitudes of the students towards individual studying could have been caused by the need for different kinds of mental skills or the possibility that the online work was found to be difficult or tedious. However, it was beyond the scope of this study to determine why students may have found the OLE difficult in terms of studying for class. However, while creating appropriate learning environments, planning should be done to reduce this reluctance and learning strategies should be prepared accordingly. Also, it was seen that it is important to provide opportunities for social interaction to develop the sense of responsibility of the students and to design online learning environments that consider individual learning differences. Thus, in the future, the use of cooperative lessons in the OLE might help to alleviate these issues further assisting EPT in overcoming their fear of science. This is an issue that must be considered when designing blended learning environments for this group of students.

In the future studies should be designed to determine if the suggested shifts in the BL activities within the SMC lead to a more productive student OLE.

\section{Elementary preservice teachers response positively to the blending of face-to-face and online learning environment}

The factor that focused on assessing the blending of the F2F and OLE environment consisted of twenty survey items that revealed the experiences and opinions of the students about the blending of the face-to-face learning environment with the online learning environment. When each item constituting the factor was analyzed separately, it was seen that the experiences and opinions of the students were all positive. A few examples of experiences and opinions of the students are as follows:

- "The teaching staff used face-to-face (in-class) and online (internet) environments effectively. (BL2)",

- "I think I learned better. (BL4)",

- "Face-to-face (in-class) and online content were suitable for the chosen environment. (BL11)",

- "There was integrity in the content taught in both environments. (BL15)", and 
- "I decided what to learn and how to learn. (BL20)."

This result showed that the in-class face-to-face learning environment and the online learning environment were appropriately blended in the eyes of the EPT. The results obtained from this study were in parallel with those obtained from similar studies. For example, after a 16-week vocational education database course conducted with blended learning, a majority of students stated that the course was useful or very useful (Tsai et al., 2011). In another study, it was concluded that the education carried out with blended learning had a significant effect on improving the learning skills and the satisfaction of learners (McKenzie et al., 2013). When these results are generally evaluated, the blending of properly designed in-class face-to-face learning environments and nonclass online learning environments has been accepted and responded to positively by the students. Thus, the traditional fear of science felt by elementary preservice teachers nor the negative aspects of the OLE diluted the normal positive effects that students in other fields have felt towards a blended learning environment.

\section{Technical dimensions of the blended course are an issue of elementary preservice teachers}

This survey factor consisted of five items that revealed the experiences and opinions of the students about the technical problems they encountered during their blended learning experience. When each item constituting the factor was analyzed separately, it was seen that all of the experiences and opinions of the students are significantly different from the expected values of 3 . This significant difference implied that students had negative experiences and opinions about technological issues.

The survey item "I felt lonely and unhappy myself (TD1)", showed that students were not comfortable in the new learning environment created by the design of the blended learning environment. This parallels the students' opinion that they felt lonely in the OLE. However, regardless of this negative aspect overall, the students' opinions about the OLE and the BL, in general, were positive. However, this is an issue that needs to be resolved since technical issues that make the student feel alone could make them frustrated and further make EPT feel that they are not "good" at science. Thus, as mentioned earlier future versions of the course should make use of strategies that allow for more engagement with others when interacting in the OLE which could alleviate this type of experience with the technical aspect of the BL course.

Student frustrations were also felt when delivering assignments since a majority of them felt they "had difficulty delivering the assignments on time (TD2)". Any technical difficulties such as this could lead to frustration on the part of the students. However, the survey did not allow for determining the specific issues students faced so it is difficult to say if these issues were technical or brought on by lack of time management. Thus, this situation needs to be examined in further detail in the future.

However, significant differences were found in the following items:

- "I have had problems with the technological infrastructure (TD3)",

- "I had technological difficulties (TD4)", and

- "I had problems with Internet connection" (TD5). 
These TD issues demonstrate that technical problems seemed to originate mostly from the use of the online learning environment which were not unexpected in the BL course. This result was similar to the results of a previous study that used blended learning practices during a general chemistry laboratory course (Yllmaz, 2017). Students stated that they had similar problems with the internet in terms of technical problems, connection problems, and the web platform's user interface. However, this must not have been a huge issue since students overall preferred the BL environment over that of a traditional F2F course. These results suggest that the OLE in BL should be designed to consider these types of technical aspects. Learning in an electronic environment requires the development of a new and unique learning culture as well as new online tools. As new environments are constructed for use in BL courses, future studies should compare their usage in SMC with EPT.

\section{Conclusions and implications}

The results and suggestions obtained from this initial study that examined the experiences and opinions of elementary preservice students towards science methods blended learning course suggested that students had an overall positive experience. Specifically, this study determined that:

- the experiences and opinions of the students about the use of blended learning in their science education methods course were generally positive,

- the use of a blended learning environment in elementary science methods courses might help to alleviate the fear of science since their level of course enjoyment was high, and

- although these learning environments can be expensive and time-consuming initially, they seem to provide a new set of tools for the education of elementary preservice teachers.

Several findings pointed towards how to design a science methods course to improve student learning within the context of a blended learning science methods course. Specifically, the majority of issues seemed to concern the online learning environment used in the blended learning course. Thus, when designing the online learning component of the course, the needs of the students should be taken into consideration, and attention should be paid to creating environments where students can communicate with teachers and other peers online. The findings suggested that the incorporation of cooperative online assignments could help to alleviate these issues and decrease the frustration felt by elementary preservice teachers.

Blended learning may be the next step for science education. Unlike existing F2F learning for science methods courses, blended learning overcame special times, special places, and special instructors and provided students learning outside-of-the classroom as well as time in class for active learning. The results of this study suggested that elementary preservice teachers preferred the use of blended learning over either the online or face to face components of the courses. This type of shift in enjoyment in a science course by EPT could help them to become more willing to use hands-on inquiry methods with their primary school students as it could support an increase in their self-efficacy towards science teaching. Overall, this could assist in helping to develop a 
more scientifically literate citizenry over time. However, to bring these innovative learning tools into widespread use in higher education and make them more effective at training elementary preservice teachers, additional research is needed.

Research needs to be conducted that will determine if science methods courses using blended learning does help to decrease teachers' fear of science and promote their subsequent use of inquiry methods with their future students. This could be determined by quasi-experimental studies assessing shifts in EPT self-efficacy for science in both a BL environment and a strictly F2F environment. An interview study could be used to assess what specific aspects of the BL pedagogy assist them in overcoming these issues. In addition, in this study, the opinions of other stakeholders such as teachers, administrators and future employers were not considered. Future studies should determine the opinions of these other stakeholders.

\section{Abbreviations}

BL: Blended learning; EPT: Elementary Preservice Teachers; SMC: Science Methods Course; F2F: Face-to-face;

OLE: Online learning Environment; BLE: Blended learning environment; TD: Technical dimensions

\section{Acknowledgements}

We would like to thank the Dr. Karen E. Irving, for her comments and suggestions on the first drafts of this research paper.

\section{Authors' contributions}

The first author was the lead researcher and completed the data analysis. The second author shared in drafting the article and reviewing the data analysis. The authors read and approved the final manuscript.

Funding

The authors declare no funding source for this research.

\section{Availability of data and materials}

The datasets generated during this study are available from the corresponding author.

Competing interests

The authors declare that they have no conflict of interest.

\section{Author details}

${ }^{1}$ Faculty of Education, Department of Mathematics and Science Education, Erzincan Binali Yildirim University, Erzincan,

Turkey. ${ }^{2}$ Graduate School of Education, Nazarbayev University, Nur-Sultan, Kazakhstan.

Received: 13 February 2020 Accepted: 29 May 2020

Published online: 18 June 2020

\section{References}

Adams, A., \& Ross, D. D. (2014). Clinical Partnership at a Distance: A design that transforms teaching and leadership. Peabody Journal of Education, 89(4), 533-546. https://doi.org/10.1080/0161956X.2014.939007.

Akgündüz, D., \& Akınoğlu, O. (2017). The impact of blended learning and social media-supported learning on the academic success and motivation of the students in science education. Education in Science, 42(191), 69-90.

Akkoyunlu, B., \& Soylu, M. Y. (2006). A study on students' views on blended learning environment. Turkish Online Journal of Distance Education, 7(3), 43-56.

Alayyar, G. M., Fisser, P., \& Voogt, J. (2012). Developing technological pedagogical contentknowledge in pre-service science teachers: Support fromblended learning. Australasian Journal of Educational Technology, 28(8), 1298-1316.

Appleton, K., \& Kindt, I. (1999). Why teach primary science? Influences on beginning teachers' practices. International Journal of Science Education, 21(2), 155-168.

Armbruster, P., Patel, M., Johnson, E., \& Weiss, M. (2009). Active learning and student-centered pedagogy improve student attitudes and performance in introductory biology. CBE Life Sciences Education, 8(3), 203-213.

Baepler, P., Walker, J. D., \& Driessen, M. (2014). It's not about seat time: Blending, flipping, and efficiency in active learning classrooms. Computers in Education, 78, 227-236 Doi:2014.06.006.

Bazeley, P. (2004). Applying qualitative methods to marketing management research. UK: Palgrave Macmillan.

Bergmann, J., \& Sams, A. (2012). Flip your classroom. USA: International Society for Technology in Education.

Bursal, M., \& Paznokas, L. (2006). Mathematics anxiety and preservice elementary teachers' confidence to teach mathematics and science. School Science and Mathematics, 106(4), 173-180.

Cabı, E., \& Gülbahar, Y. (2013). Harmanlanmış öğrenme ortamlarının etkililiğinin ölçülmesi için bir ölçek geliştirme çalışması. Pegem Eğitim ve Öğretim Dergisi, 3(3), 11-26.

Caulfield, J. (2011). How to design and teach a hybrid course. Sterling: Stylus.

Cooligan, H. (1999). Research methods and statistics in psychology (2nd ed.). Hodder and Stoughton. https://books.google.com. tr/books?id=XmfGQgAACAAJ\&dq=inauthor:\%22Hugh+Coolican\%22\&hl=tr\&sa=X\&redir_esc=y. 
Crawford, A., Saul, W., Mathews, S. R., \& Makinster, J. (2005). Teaching and learning strategies for the thinking classroom. New York: The International Debate Education Association.

Creswell, J. W. (2012). Educational research: Planning, conducting, and evaluating quantitative and qualitative research. USA: Pearson Education, Inc..

Demirer, V., \& Sahin, I. (2013). Effect of blended learning environment on transfer of learning: An experimental study. Journal of Computer Assisted Learning, 29(6), 518-529. https://doi.org/10.1111/jcal.12009.

Field, A. (2009). Discovering statistics using SPSS. London: SAGE Publications Ltd.

Garrison, D. R., \& Vaughan, N. D. (2008). Blended learning in higher education. San Francisco: Jossey-Bass.

Gould, J. E. (2002). Concise handbook of experimental Methodsforthe behavioral Andbiological sciences. Boca Raton: CRC Press LLC.

Graham, C. R. (2006). Blended learning systems: Definition, current trends, and future directions. In C. J. B. C. R. Graham (Ed.), The handbook of blended learning: Global perspectives, local designs (pp. 3-21). San Francisco: Pfeiffer.

Graham, C. R. (2017). Thematic patterns in international blended learning literature, research, practices, and terminology. Online Learning, 21(4), 337-361. https://doi.org/10.24059/olj.v21i4.998.

Gravetter, F. J., \& Wallnau, L. B. (2007). Statistics for the behavioral sciences. Belmont: Thomson Wadsworth.

Harris, L. (2011). Secondary teachers' conceptions of student engagement: Engagement in learning or in schooling? Teaching and Teacher Education, 27(2), 376-386. https://doi.org/10.1016/j.tate.2010.09.006.

Heba, E. D., \& Nouby, A. (2008). Effectiveness of a blended e-learning cooperative approach in an Egyptian teacher education programme. Computers in Education, 51(3), 988-1006.

Hitchcock, D. H., Hitchcock, G., \& Hughes, D. (1995). Research and the teacher: A qualitative introduction to school-based research. London: Routledge. https://www.amazon.com/Research-Teacher-Qualitative-Introduction-School-based/dp/ 0415101026\#reader_0415101026.

Hoskin, L. (2011). Parametric and nonparametric: Demystifying the terms. New York: Wiley.

Jahjouh, Y. M. A. (2014). The effectiveness of blended E-learning forum in planning for science instruction. Journal of Turkish Science Education, 11(4), 3-16.

Jeong, J., Cañada-Cañada, \& González-Gómez, D. (2018). The study of flipped-classroom for pre-service science teachers. Education sciences. Education in Science, 8(4), 163.

Kent State University Libraries. (2017). SPSS tutorials: One sample t-test Retrieved from http:/libguides.library.kent.edu/SPSS/ IndependentTTest.

King, K. P. (2002). Identifying success in online teacher education and professional development. The Internet and Higher Education, 5(3), 231-246.

Krathwohl, D. R. (2010). A revision of Bloom's taxonomy: An overview. Theory Into Practice, 41(4), $212-218$.

Kurt, G. (2017). Implementing the flipped classroom in teacher education evidence from Turkey. Journal of Educational Technology \& Society, 20(1), 211-221.

Lee, J.-S. (2012). The effects of the teacher-student relationship and academic press on student engagement and academic performance. International Journal of Educational Research, 53, 330-340. https://doi.org/10.1016/j.jijer.2012.04.006.

Lim, D. H., \& Morris, M. L. (2009). Learner and instructional factors influencing learning outcomes within a blended learning environment. Journal of Educational Technology \& Society, 12(4), 282-293.

Linder, K., \& E. (2017). The blended course design workbook: A practical guide. Sterling: Stylus Publishing, LLC.

Lodico, M. G., Spaulding, D. T., \& Voegtle, K. H. (2006). Methods in educational research. San Francisco: Jossey-Bass.

Martínez-Caro, E., \& Campuzano-Bolarín, F. (2011). Factors affecting students' satisfaction in engineering disciplines: Traditional vs. blended approaches. European Journal of Engineering Education, 36(5), 473-483.

McKenzie, W. A., Perini, E., Rohlf, V., Toukhsati, S., Conduit, R., \& Sanson, G. (2013). A blended learning lecture delivery model for large and diverse undergraduate cohorts. Computers in Education, 64, 116-126. https://doi.org/10.1016/j.compedu. 2013.01.009.

Means, B., Toyama, Y., Murphy, R., \& Baki, M. (2013). The effectiveness of online and blended learning: A meta-analysis of the empirical literature. Teachers College Record, 115(3), 1-47.

Means, B., Toyama, Y., Murphy, R., Bakia, M., \& Jones, K. (2010). Evaluation of evidence-based practices in online learning: A metaanalysis and review of online learning studies. Washington DC: Retrieved from http://www2ed.gov/rschstat/eval/tech/ evidence-based-practices/finalreport.pdf.

Motteram, G. (2006). 'Blended' education and the transformation of teachers: A long-term case study in postgraduate UK higher education. British Journal of Educational Technology, 37(1), 17-30

Murray, J. F. (2013). Likert data: What to use, parametric or non-parametric? International Journal of Business and Social Science, $4(11), 258-264$

Namyssova, G., Tussupbekova, G., Helmer, J., Malone, K., Afzal, M., \& D, J. (2019). Challenges and benefits of blended learning in higher education. International Journal of Technology in Education, 2(1), 22-31.

OECD. (2006). 21st century learning environments. Innovation in Education, 108. http://www.oecd.org/education/innovationeducation/21stcenturylearningenvironments.htm.

OECD. (2019). Education at a glance 2019: OECD indicators. Paris: OECD publishing.

Oikawa, Y., Nakajima, K., Matsuba, R., Suzuki, K., Kita, T., \& Nakano, H. (2013). Designing a blended undergraduate general chemistry course using the ARCS model. Aichi: Paper presented at the International Conference for Media in Education, Nihon Fukushi University.

Oppermann, E., Brunner, M., \& Anders, Y. (2019). The interplay between preschool teachers' science self-efficacy beliefs, their teaching practices, and girls' and boys' early science motivation. Learning and Individual Differences, 70, 86-99. https://doi. org/10.1016/j.lindif.2019.01.006.

Owens, D. C., Sadler, T. D., Barlow, A. T., \& Smith-Walters, C. (2017). Student motivation from and resistance to active learning rooted in essential science practices. Research in Science Education. https://doi.org/10.1007/s11165-017-9688-1.

Owston, R. d., Sinclair, M., \& Wideman, H. (2008). Blended learning for professional development: An evaluation of a program for middle school mathematics and science teachers. Teachers College Record, 110(5), 1033-1064.

Picciano, A. G. (2009). Blending with purpose: The multimodal model. Journal of Asynchronous Learning Networks, 13(1), 7-18. 
Riegle-Crumb, C., Morton, K., Moore, C., Chimonidou, A., Labrake, C., \& Kopp, S. (2015). Do inquiring minds have positive attitudes? The science education of preservice elementary teachers. Science Education, 99(5), 819-836. https://doi.org/10. 1002/sce.21177.

Ross, D., Adams, A., Bondy, E., Dana, N., Dodman, S., \& Swain, C. (2011). Preparing teacher leaders: Perceptions of the impact of a cohort-based, job embedded, blended teacher leadership program. Teaching and Teacher Education, 27(8), 12131222. https://doi.org/10.1016/j.tate.2011.06.005

Smith, J., Groves, M., Bowd, B., \& Barber, A. (2012). Facilitating the development of study skills through a blended learning approach. International Journal of Higher Education, 1(2), 108-117. https://doi.org/10.5430/ijhe.v1n2p108.

Spring, K. J., Graham, C. R., \& Hadlock, C. A. (2016). The current landscape of international blended learning. International Journal of Technology Enhanced Learning, 8(1), 84-102.

Stein, J., \& Graham, C. R. (2014). Essentials for blended learning a standards-based guide. New York: Routledge.

Tabata, L. N., \& Johnsrud, L. K. (2008). The impact of faculty attitudes toward technology, distance education, and innovation. Research in Higher Education, 49(7), 625-646.

Tomas, L., Doyle, T., \& Skamp, K. (2019). Are first year students ready for a flipped classroom? A case for a flipped learning continuum. International Journal of Educational Technology in Higher Education, 16(1). https:// educationaltechnologyjournal.springeropen.com/articles/10.1186/s41239-019-0135-4\#citeas.

Tosun, T. (2000). The beliefs of pre-service elementary teachers toward science and science teaching. School Science and Mathematics, 100, 374-379.

Tsai, C.-W., Shen, P.-D., \& Tsai, M.-C. (2011). Developing an appropriate design of blended learning with web-enabled selfregulated learning to enhance students' learning and thoughts regarding online learning. Behaviour \& Information Technology, 30(2), 261-271. https://doi.org/10.1080/0144929X.2010.514359.

Webb, M. (2008). Impact of it on science education. In I. J. Voogt \& G. Knezek (Eds.), International handbook of information Technology in Primary and Secondary Education (pp. 133-148). New York: Springer Science+Business Media, LLC.

Willingham, D. T. (2009). Why don't students like school?: A cognitive scientist answers questions about how the mind works and what it means for your classroom. USA: Jossey-Bass.

Yeh, Y.-C. (2010). Integrating collaborative PBL with blended learning to explore preservice teachers' development of online learning communities. Teaching and Teacher Education, 26(8), 1630-1640. https://doi.org/10.1016/j.tate.2010.06.014.

Yılmaz, Ö. (2017). Blended learning in science instruction: General chemistry laboratory application. Erzincan University Journal of Education Faculty, 9(3), 72-85. https://doi.org/10.17556/erziefd.315041.

Zhang, Y., Zhang, H., \& Seiler, M. J. (2014). Integrating lectures and experiments in the teaching of real estate investments a blended learning approach. Journal of Real Estate Practice and Education, 17(1), 31-52.

Zucker, A. A. (2008). Transforming schools with technology. Cambridge: Harward Education Press.

\section{Publisher's Note}

Springer Nature remains neutral with regard to jurisdictional claims in published maps and institutional affiliations.

\section{Submit your manuscript to a SpringerOpen ${ }^{\circ}$ journal and benefit from:}

- Convenient online submission

Rigorous peer review

- Open access: articles freely available online

- High visibility within the field

- Retaining the copyright to your article

Submit your next manuscript at $\boldsymbol{s p r i n g e r o p e n . c o m ~}$ 